\title{
A chironomid-based Holocene summer air temperature reconstruction from the Swiss Alps
}

\author{
Oliver Heiri, ${ }^{1 *}$ André F. Lotter, ${ }^{1}$ Sonja Hausmann ${ }^{2}$ and \\ Felix Kienast ${ }^{3}$
}

\author{
( ${ }^{1}$ Botanical Palaeoecology, Laboratory of Palaeobotany and Palynology, Utrecht \\ University, Budapestlaan 4, NL-3584 CD Utrecht, Netherlands; ${ }^{2}$ Centre \\ d'Etudes Nordiques, Université Laval, Quebéc (Quebéc) G1K 7P4, Canada; \\ ${ }^{3}$ Swiss Federal Institute for Forest, Snow and Landscape Research (WSL), \\ Zürcherstrasse 111, CH-8903 Birmensdorf, Switzerland)
}

Received 17 July 2002; revised manuscript accepted 23 December 2002

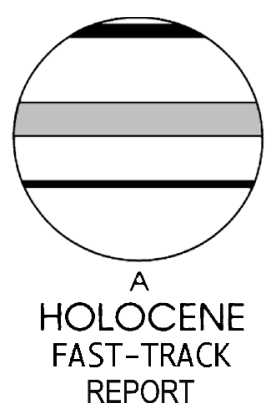

\section{Introduction}

Palaeotemperature reconstructions provide an important basis for understanding the dynamics and functioning of the climatic system. Observed recent temperature trends must be assessed in relation to the natural, long-term dynamics of the climatic system (Bradley, 2000). Furthermore, accurate temperature reconstructions are necessary to evaluate climate models that enhance our understanding of global climate dynamics and are ultimately used to predict future climate under changed boundary conditions (e.g., COHMAP Members, 1988; Renssen and Isarin, 1998). Instrumental temperature records are generally only available from the last 100 to 150 years. Temperature proxies, e.g., isotope records from ice cores or lake sediments, tree-ring sequences or fossil remains of organisms in sediments, provide an alternative means of recon-

*Author for correspondence (e-mail: o.heiri@bio.uu.nl) structing past temperatures (e.g. Schweingruber et al., 1991; GRIP members, 1993; von Grafenstein et al., 1998; Lotter et al., 2000). Many of these records provide continental temperature estimates covering a large part of the Holocene, some even reaching back to the Lateglacial period.

In the Alps, a number of palaeobotanical studies have provided evidence of past temperature fluctuations (e.g., Patzelt, 1977; Bircher, 1986; Lang, 1993). Since the upper limit of tree-growth in mountain regions is closely related to temperatures during the growing season (Tranquillini, 1979; Dahl, 1986), one of the most convincing approaches to infer past Alpine summer temperatures is to reconstruct former treeline elevations (e.g., Patzelt, 1977; Burga and Perret, 1998). Using plant macrofossil and pollen records from lakes at present-day treeline, Wick and Tinner (1997) described a number of partly synchronous treeline oscillations from the central and southern Alps that agree with other temperature reconstructions in the Alpine region (Haas et al., 
1998). However, reconstructing past treelines based on pollen analysis is difficult due to the bias of long-distance pollen transport (Lang, 1993). If past treeline fluctuations are to be used to provide quantitative estimates of past summer temperatures, plant macrofossils (or fossil stomata; Ammann and Wick, 1993) need to be analysed in a number of lakes across an altitudinal gradient in order to constrain former treeline altitudes.

Alternatively, organism-based inference models can be used to provide a direct estimate of past temperatures from fossil assemblages (Birks, 1995; Lotter et al., 1997). Subfossil remains of chironomid larvae (Insecta: Diptera: Chironomidae) from lake sediments have proven to be particularly useful temperature indicators (Walker et al., 1991b; Battarbee, 2000). Along a large climatic gradient summer temperature is commonly the environmental factor explaining the most variance in subfossil chironomid assemblages (e.g., Walker et al., 1991b; Lotter et al., 1997). Thus, a number of chironomid-summer temperature inference models have been developed and successfully used to reconstruct the major climatic fluctuations of the Lateglacial (e.g. Walker et al., 1991a; Levesque et al., 1993; Brooks and Birks, 2000a; 2000b). However, only few chironomid-based reconstructions are available for the Holocene (e.g., Smith et al., 1998; Pellatt et al., 2000; Rosén et al., 2001). This may be because the prediction errors of the models (expressed as root mean square error of prediction; RMSEP) are generally of the same magnitude or larger than the expected Holocene temperature changes. Furthermore, during the Holocene factors such as vegetation changes, lake infilling and early human impact (e.g., catchment clearcutting and pasturing) may have a stronger influence on the lakes than temperature (e.g., Renberg et al., 1993; Korsman et al., 1994; Francis, 2001) and may therefore cause a bias in chironomid-inferred temperature reconstructions.

In this study, we present an extended chironomid-July air temperature inference model that is used to reconstruct Holocene temperatures at Hinterburgsee, a small lake in the subalpine belt of the Bernese Alps, Switzerland. Chironomid assemblages at this altitude in the northern Swiss Alps seem to be particularly sensitive to changes in summer air temperature (Lotter et al., 1997). Furthermore, as these subalpine lakes commonly feature high sedimentation rates, they can produce environmental reconstructions of a high temporal resolution.

\section{Site and methods}

Hinterburgsee $\left(46^{\circ} 43^{\prime} 07^{\prime \prime} \mathrm{N}, 8^{\circ} 04^{\prime} 07^{\prime \prime} \mathrm{E}\right)$ is a small lake in the subalpine vegetation zone at $1515 \mathrm{~m}$ a.s.l. in the Bernese Alps, Switzerland (Figure 1). It is located above the southern shore of Lake Brienz, c. $16 \mathrm{~km}$ east of Interlaken and $4.5 \mathrm{~km}$ south to southwest of Brienz, and features a present-day mean July air temperature of $11.3^{\circ} \mathrm{C}$. In summer 1998 , a sediment core reaching back into the Lateglacial period was recovered from the deepest part of the lake (see Heiri et al., 2003, for details on the site, subfossil chironomid record and age-depth modelling). Sixteen samples of terrestrial plant remains from the sediment were dated using accelerator mass spectrometer (AMS) radiocarbon dating. Together with a palynological date (Younger Dryas/Holocene boundary) they provided the basis of an age-depth model reaching back to $c .11500$ calibrated radiocarbon years BP (cal. BP). The age-depth modelling (Figure 2) is based on non-parametric weighted regression within the framework of Generalized Additive Models (Hastie and Tibshirani, 1990) and on radiocarbon dates calibrated using the CALIB 4.1.2. program (Stuiver and Reimer, 1993). Lateglacial ages were estimated by linear extrapolation beyond the Holocene/Younger Dryas boundary. A total of 62 sediment samples were analysed for subfossil chironomids (Figure 3; Heiri et al., 2003). Depending on the sediment depth,

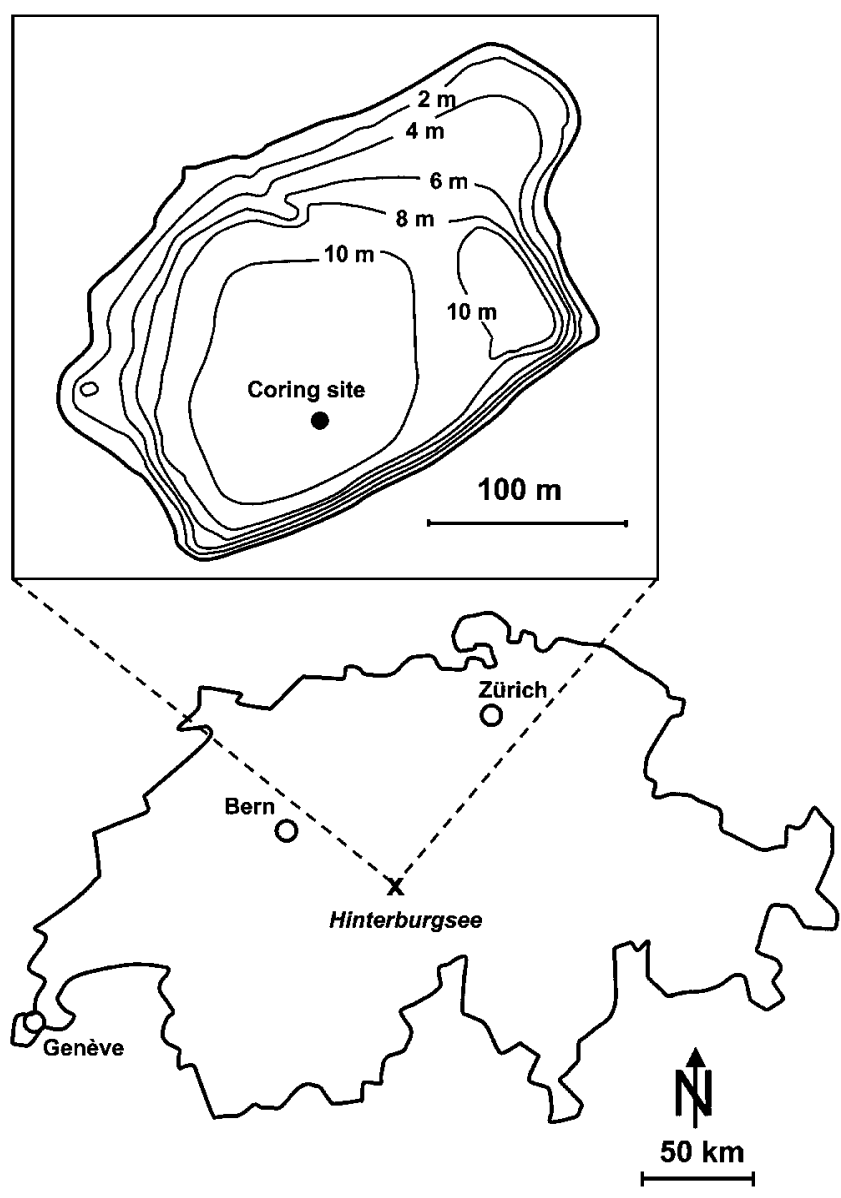

Figure 1 Contour map of Switzerland showing the location of Hinterburgsee. The inset map shows the lake bathymetry (following Spengler, 1973, changed) and the coring site within the lake basin.

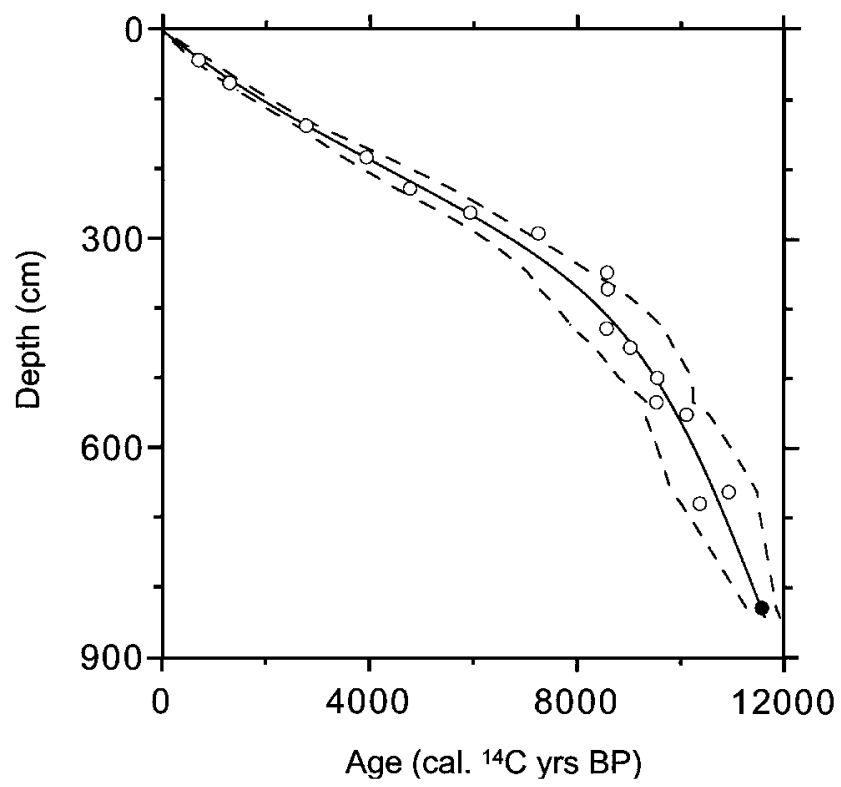

Figure 2 Dating of the Hinterburgsee sediment core: age-depth model (solid line) and 95\% confidence intervals (dashed lines). Open circles indicate the calibrated radiocarbon dates used for the model; the closed circle indicates a pollen-inferred age.

a single sample encompassed between 10 and 50 years of sedimentation and the chironomid record has a resolution of about one sample every 100-300 years.

A chironomid-July air temperature inference model was developed using surface-sediment samples obtained from 89 small 


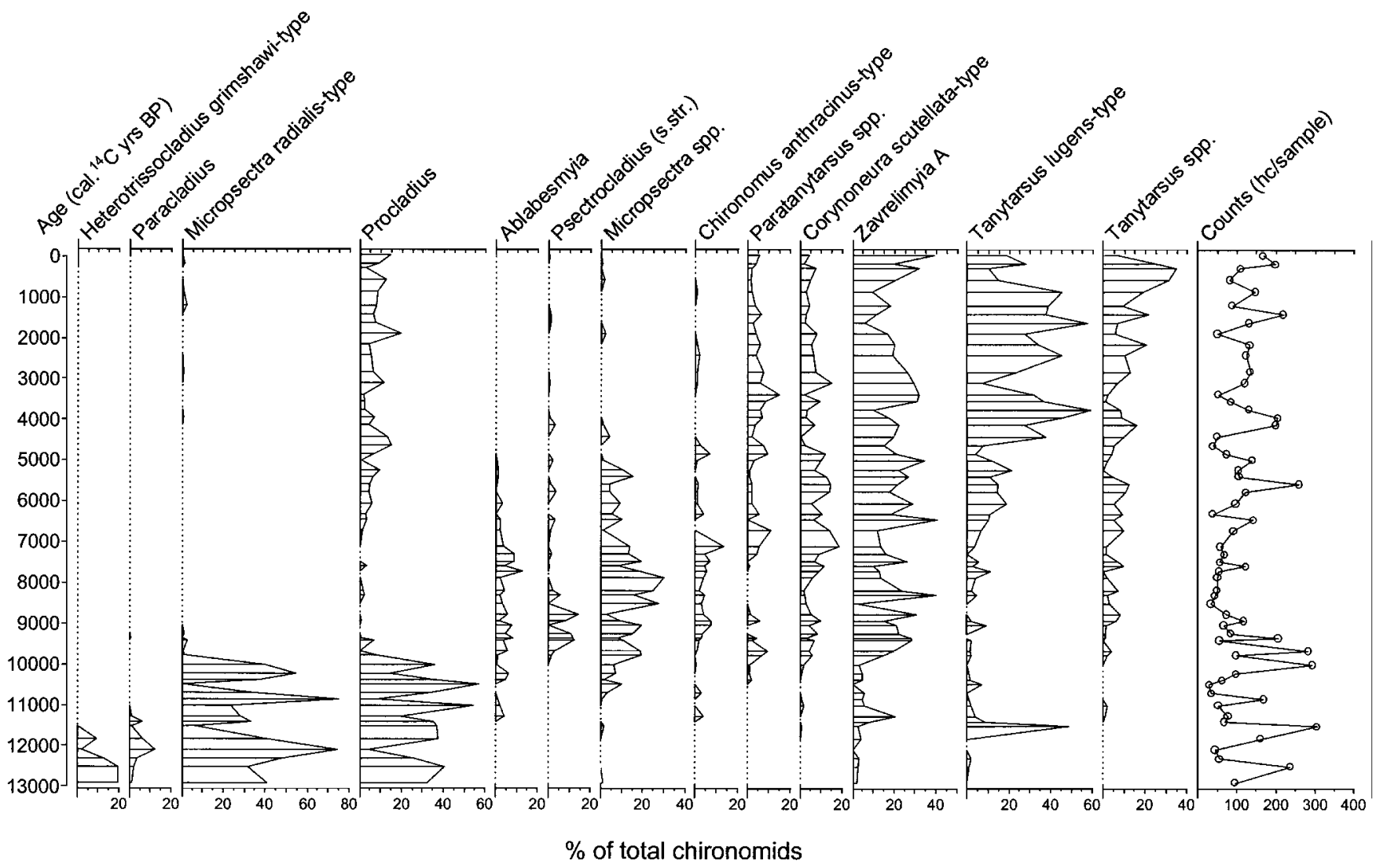

Figure 3 Summary diagram of the most common chironomid taxa recovered from the Hinterburgsee sediments (see Heiri et al., 2003, for a detailed description of the subfossil chironomid record). Abundances for the individual taxa are given as percentages and the counts as head capsules (hc) per sample.

Swiss lakes (following the methodology described in Lotter et al., 1997). Results of 50 of these lakes have been previously published (Lotter et al., 1997). However, for the present study all the original slides have been re-examined to increase the taxonomic resolution and to harmonize the taxonomy with the downcore record. GIS-based mean July air temperature was estimated for each lake following Lotter et al. (1997). Further information on the lakes is given in Lotter et al. (1997; 1998); Müller et al. (1998) and Heiri (2001).

The chironomid-July air temperature inference model was developed using the program CALIBRATE (S. Juggins and C.J.F. ter Braak, unpublished software) and sample specific error estimates were calculated by 999 bootstrap cycles using the program WAPLS (S. Juggins and C.J.F. ter Braak, unpublished software). Analogue and goodness-of-fit statistics were calculated following Birks et al. (1990), Birks (1995), Jones and Juggins (1995) and Birks (1998). A cut-level of the 5th and the 10th percentile in the modern residual chi-square distances was chosen for samples with a 'very poor' and a 'poor' fit to temperature and a cut level of the 2 nd and 5th percentile of all chi-square distances within the modern data for samples with no 'close' and no 'good' analogues, respectively. Furthermore, we calculated the percentage of rare taxa for each fossil sample, where rare taxa are defined as having a Hill's $\mathrm{N}_{2}$ (Hill, 1973) of 5 or less in the modern chironomid data. Canonical Correspondence Analysis (CCA) and Detrended Canonical Correspondence Analysis (DCCA) were accomplished using CANOCO version 4.0 (ter Braak and Smilauer, 1998) and analogues calculated using MAT (S. Juggins, unpublished software). Smoothing of the inferred July air temperatures was achieved by fitting a LOESS model (Cleveland and Devlin, 1988) with a gaussian error distribution, a locally linear fitting and a span of 0.1 to the data points using the program SPLUS 4.5 (MathSoft, Inc.). For all calculations the chironomid percentage data were square-root transformed.

\section{Results}

\section{July air temperature inference model}

Chironomid data and July air temperatures of 89 lakes from the Jura Mountains, the northern Swiss lowland and the northern and central Swiss Alps were available for regression of the chironomid-July air temperature inference model. In order to reduce noise in the chironomid data due to low counts, the minimum count level was set to 45 (Heiri and Lotter, 2001), leading to the exclusion of four lakes from the analysis. One sample was eliminated from the regression as it was dominated by a single taxon absent in the subfossil chironomid record of Hinterburgsee and otherwise rare in Swiss lakes. Three further lakes were eliminated as they are used as regulating basins for hydropower generation or subject to occasional flooding by a nearby river. In the remaining samples, taxa with fewer than three occurrences were deleted. The final data set contained 76 chironomid taxa and 81 samples spanning an altitudinal range from 420 to $2490 \mathrm{~m}$ a.s.l. and featuring observed mean July air temperatures from 6.9 to $18.4^{\circ} \mathrm{C}$. In a Detrended Canonical Correspondence Analysis (DCCA) with July air temperature as the only constraining variable the first axis featured a gradient length of 2.7 standard deviation units, indicating that unimodal-based regression techniques are appropriate (Birks, 1995). Furthermore, the analysis revealed a significant secondary gradient in the chironomid data (length of DCA axis 2 of 3.1 standard deviations, significance assessed following Birks, 1998). In a Canonical Correspondence Analysis (CCA), July air temperature explained $13.1 \%$ of the variance in the chironomid data and was highly significant $(P<0.0001)$ when tested by a Monte Carlo permutation test (9999 unrestricted permutations; ter Braak, 1990; 1992; Birks, 1998).

Weighted averaging-partial least squares regression (WAPLS; ter Braak and Juggins, 1993; ter Braak et al., 1993) with two components yielded a chironomid-July air temperature inference 
model with a coefficient of determination $\left(\mathrm{r}^{2}\right)$ of 0.81 and a root mean square error of prediction (RMSEP) of $1.51^{\circ} \mathrm{C}$ as assessed by leave-one-out cross-validation(Figure 4). As expected in a data set with a strong secondary gradient (Birks, 1998), it outperformed weighted averaging (WA) with classical deshrinking $\left(\mathrm{r}^{2}=0.74\right.$, RMSEP $\left.=1.96^{\circ} \mathrm{C}\right)$, WA with inverse deshrinking $\left(\mathrm{r}^{2}\right.$ $=0.74$, RMSEP $=1.77^{\circ} \mathrm{C}$ ) and WA methods with tolerance downweighting $\left(r^{2}=0.60-0.64\right.$, RMSEP $=2.23-2.40^{\circ} \mathrm{C}$; see Birks, 1995 , for details on these WA-based methods). WAPLS with three components provided only slightly better model statistics $\left(\mathrm{r}^{2}\right.$ $=0.82, \operatorname{RMSEP}=1.47^{\circ} \mathrm{C}$ ) and the simpler two-component model was therefore retained. The two-component WAPLS model has a tendency to infer too high temperatures at the cold end of the temperature gradient (Figure 4), but these edge effects do not influence temperatures close to the present-day July air temperature of $11.3^{\circ} \mathrm{C}$ at Hinterburgsee. Finally, the model was tested for statistical outliers following the approach of Lotter et al. (1997), but, as no sample combined the attributes of a high absolute residual and a low Cook's D or a high absolute residual, a high Cook's D and a very high residual chi-square distance in a CCA, no further lakes were excluded from the model.

\section{Temperature reconstruction}

The two-component WAPLS model was applied to the Hinterburgsee downcore data consisting of 62 samples and 50 chironomid taxa (Figure 3; Heiri et al., 2003). The inferred July air temperatures ranged from 10.1 to $13.8^{\circ} \mathrm{C}$ (Figure 5a). For samples older than $11500 \mathrm{cal}$. BP, the model reconstructs low temperatures between 10.1 and $11.0^{\circ} \mathrm{C}$. Inferred temperatures in the first part of the Holocene (11500 to $5000 \mathrm{cal}$. BP) fluctuate strongly and range from 10.4 to $13.8^{\circ} \mathrm{C}$. In samples younger than 5000 cal. BP, the inferences tend to be more stable with a July air temperature range of 10.7 to $13.3{ }^{\circ} \mathrm{C}$. Due to the high betweensample variability it is difficult to detect an overall Holocene trend in the reconstructed temperatures. Besides a number of singlesample maxima and minima, two periods with lower temperatures are apparent during the Holocene, i.e., a two-sample event of $10.4-11.1^{\circ} \mathrm{C}$ from $c .10700$ to $10500 \mathrm{cal}$. BP and a four-sample event of $10.6-11.6^{\circ} \mathrm{C}$ between $c .8300$ and $7700 \mathrm{cal}$. BP. Furthermore, inferred temperatures in the last four samples $(600 \mathrm{cal}$. BP to present) are consistently high, ranging from 12.0 to $12.8^{\circ} \mathrm{C}$.

The strong fluctuations of the inferred temperatures in the early Holocene are not surprising as the Hinterburgsee subfossil

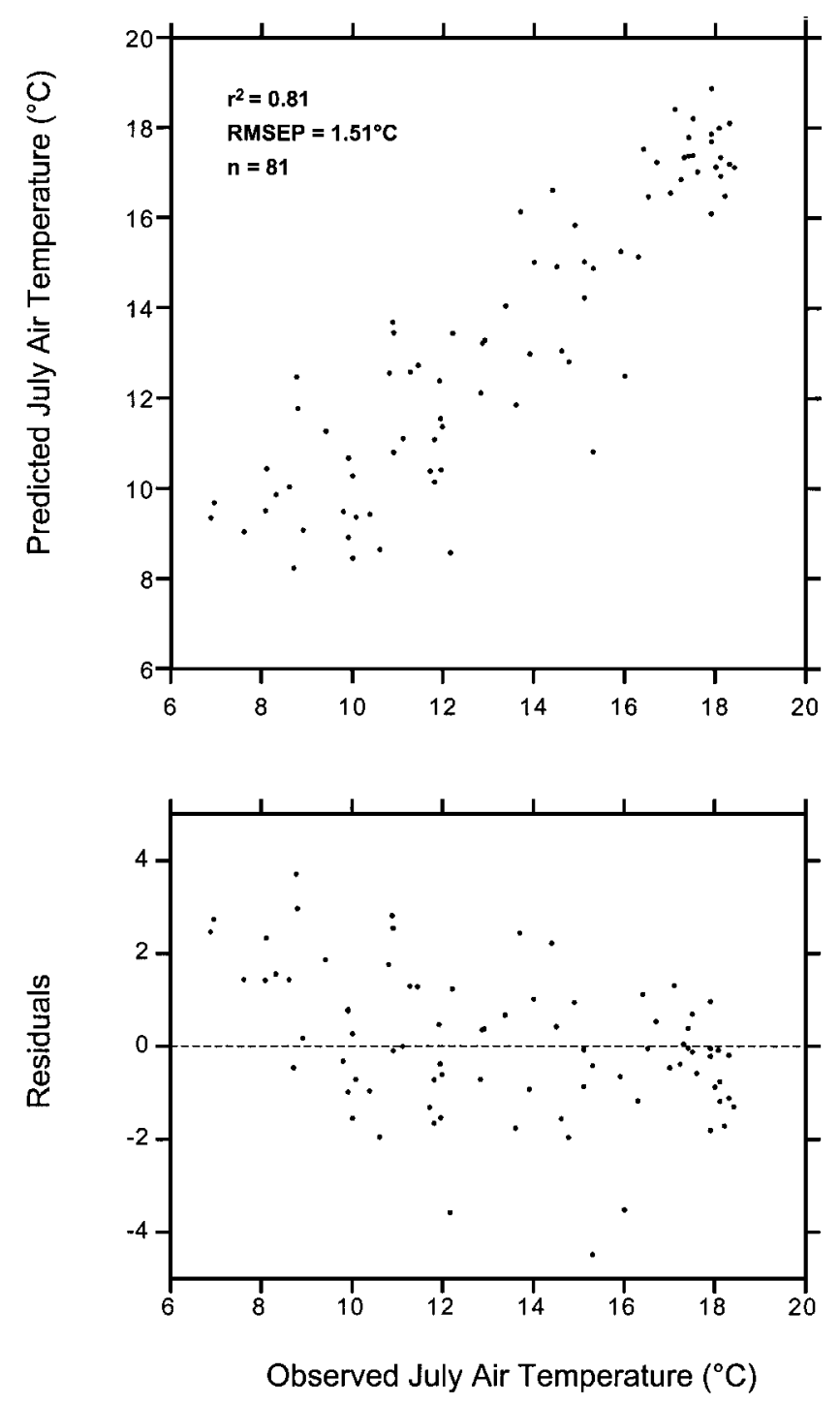

Figure 4 Predicted temperatures and prediction residuals in the chironomid-July air temperature inference model plotted against the observed temperatures. 'RMSEP' indicates the leave-one-out cross-validated root mean square error of prediction, ' ${ }^{2}$ ' the leave-one-out cross-validated coefficient of determination and ' $\mathrm{n}$ ' the number of samples. 

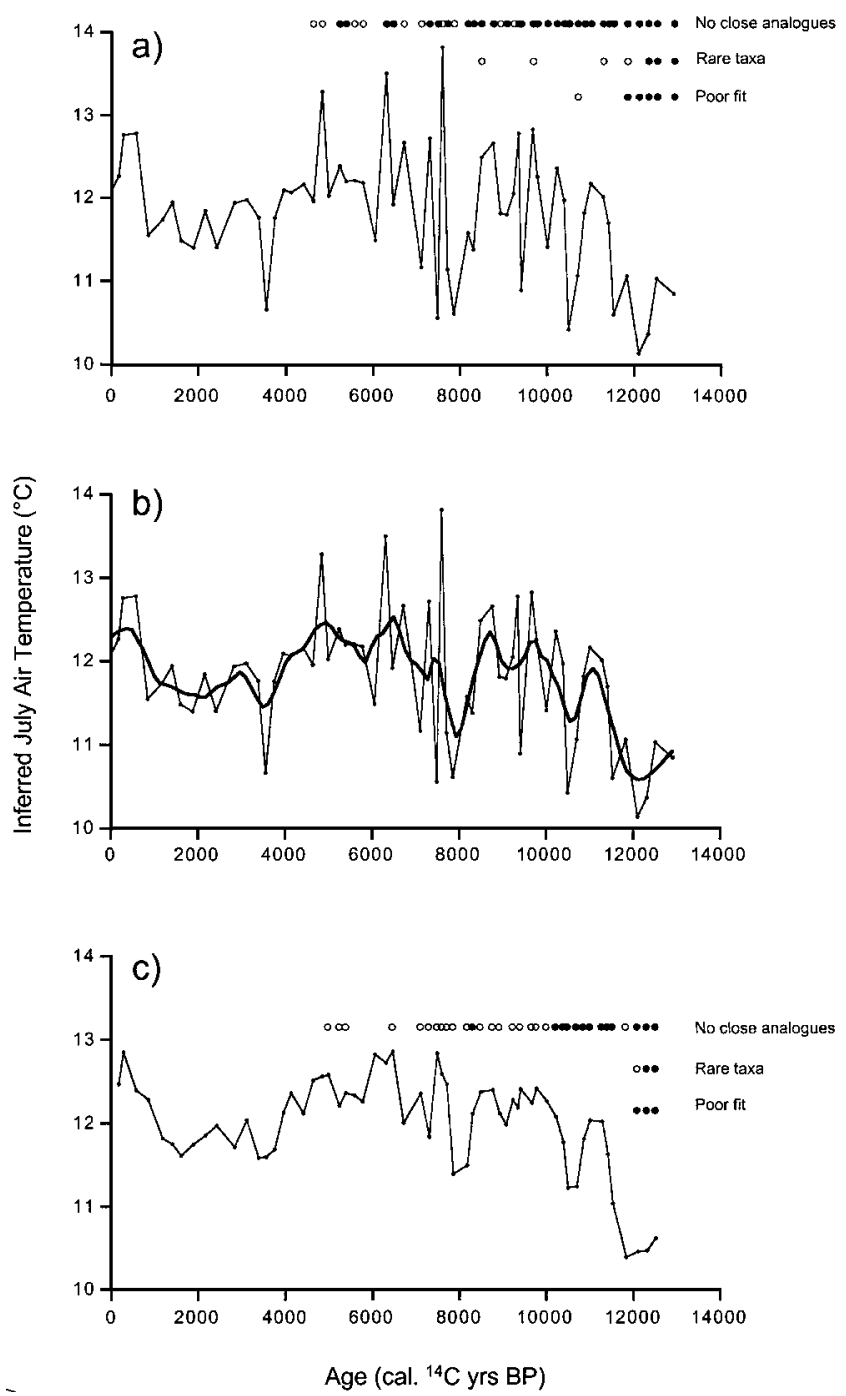

Figure 5 Holocene chironomid-inferred July air temperatures for Hinterburgsee: (a) unsmoothed inferences; (b) LOESS smoother applied to the inferred temperatures; (c) a three-sample running mean applied to the chironomid percentage data prior to reconstruction. The open/solid circles above (a) and (c) indicate samples with no close/no good modern analogue, with more than $5 \%$ /more than $10 \%$ rare taxa and with a poor/very poor fit to temperature, respectively (see text for details).

chironomid record is characterized by a high between-sample variability of subfossil assemblages (Figure 3; Heiri et al., 2003). This may be partly due to the low number of counts in some early-Holocene samples (seven samples with counts between 27 and 44; Figure 3), as this can cause a high amount of variability or even a bias in chironomid-based temperature reconstruction (Heiri and Lotter, 2001). On the other hand, a large amount of noise irrespective of the count sum seems to be typical of subfossil chironomid records from Swiss subalpine and alpine lakes (Heiri, 2001). In an attempt to increase the signal-to-noise ratio in the temperature reconstruction, we applied two different approaches. First, a LOESS smoother was calculated on the basis of the inferred temperatures and, second, a three-sample running mean was applied to the chironomid percentage data prior to square root transformation and temperature reconstruction (henceforth referred to as reconstruction 1 and reconstruction 2, respectively). The two methods produced very similar results (Figure 5, b and c). In both smoothed temperature reconstructions, Lateglacial temperatures between 10.4 and $10.9^{\circ} \mathrm{C}$ were inferred. The earliest Holocene is marked by a strong increase of July air temperatures, reaching a plateau of $c .11 .9-12.0^{\circ} \mathrm{C}$. A first major temperature reversal is apparent between 10700 and $10500 \mathrm{cal}$.
BP with temperatures of $11.2-11.3^{\circ} \mathrm{C}$. From 10200 to $4000 \mathrm{cal}$. $\mathrm{BP}$, inferred temperatures were generally between 11.9 and $12.8^{\circ} \mathrm{C}$, although a second temperature reversal with temperatures of $11.1-11.5^{\circ} \mathrm{C}$ is apparent between $c .8200$ and $7700 \mathrm{cal}$. BP. Around $4000 \mathrm{cal}$. BP, temperatures drop again and reach a local minimum of $11.5-11.6^{\circ} \mathrm{C}$ at c. 3600-3300 cal. BP. In younger samples, the inferred July air temperatures generally lie between 11.5 and $12.0^{\circ} \mathrm{C}$, but they increase again during the last $c .1000$ years to values around $12.4-12.8^{\circ} \mathrm{C}$.

\section{Numerical evaluation}

An important consideration when applying quantitative organismbased reconstruction methods to palaeoecological data is the numerical evaluation of the results (Birks, 1998). Inference models produce numbers even if the modern calibration data set does not contain the necessary ecological information to reliably reconstruct past environments from the fossil samples of interest. Following Birks et al. (1990), Birks (1995) and Birks (1998), we therefore calculated for every sample goodness-of-fit and analogue statistics, the percentage of taxa not occurring in the modern data set, the percentage of rare taxa and the sample specific RMSEP.

Of all samples in the Hinterburgsee subfossil chironomid record, $66 \%$ have no close analogue and $48 \%$ no good analogue in the modern data, although only samples older than $4000 \mathrm{cal}$. BP are affected by analogue problems (Figure 5a). Only a single Holocene sample shows a poor fit to July air temperature, whereas all Lateglacial samples have a very poor fit to temperature (Figure 5a). The maximum abundance of taxa not occurring in the modern data set was below $2.5 \%$ in any given sample of the Hinterburgsee record. However, three early-Holocene and four Lateglacial samples have more than $5 \%$ chironomid counts of rare taxa and three Lateglacial samples more than $10 \%$ (Figure 5a). The maximum percentage of rare taxa in any sample is $20 \%$. The sample-specific RMSEPs range from 1.56 to $1.79^{\circ} \mathrm{C}$ and are only slightly higher than the overall error estimate of the model (103-120\%).

In the smoothed percentage data, all validation criteria are improved. Only $55 \%$ of all samples remain with no close analogue and 22\% without good analogue (Figure 5c). Furthermore, samples with a poor or very poor fit to temperature and with more than 5\% rare taxa are restricted to the Lateglacial. Sample-specific estimates for the RMSEP range from 1.55 to $1.70^{\circ} \mathrm{C}$ (103-112\% of the overall RMSEP of the model) and in $90 \%$ of the samples these are smaller than in the unsmoothed chironomid record.

\section{Discussion}

\section{Reliability of inferred temperatures}

During the Holocene, many samples in the Hinterburgsee subfossil chironomid record do not have close or good analogues in the modern chironomid data. In contrast, samples with a poor fit to temperature are restricted to the Lateglacial and in some few cases to the earliest Holocene. Furthermore, at least $80 \%$ of the subfossil taxa in any one sample are well represented in the modern calibration data set. The fact that the analogue situation is markedly improved in the smoothed percentage data suggests that the poor analogues are caused to a significant extent by the high variability and by low count sums in the chironomid data, rather than by a Holocene chironomid fauna uncommon in modern lakes. In Hinterburgsee, a number of taxa common in the Lateglacial survived almost 2000 years into the Holocene (Heiri et al., 2003). This produced mixed faunal assemblages of alpine and subalpine elements found nowhere in modern Swiss lakes, thereby causing the poor analogue situation in the earliest Holocene. Nevertheless, WAPLS performs relatively well in poor analogue situations 
(Birks, 1998). As more than $95 \%$ of the chironomids in any sample in the smoothed Holocene record are well represented in the modern data and the inferred 'poor analogue' temperatures are not at the edge of the temperature gradient, it is expected that the smoothed reconstruction provides reasonable temperature estimates even for the earliest Holocene. However, it should be remembered that smoothing invariably introduces a bias to the reconstruction, as the timescale is slightly distorted and extreme values are corrected towards the local mean.

\section{Long-term trends}

Towards the end of the Younger Dryas mean July air temperatures around $10.4-10.9^{\circ} \mathrm{C}$ are inferred at Hinterburgsee (Figure 5, b and c). Temperature reconstructions from nearby Gerzensee $(603 \mathrm{~m}$ a.s.l.), based on pollen and Cladocera, infer mean summer (June, July, August) air temperatures of $9-10^{\circ} \mathrm{C}$ during this period (Lotter et al., 2000). At present, mean July air temperatures in the Swiss Alps are highly correlated to and approximately $1^{\circ} \mathrm{C}$ higher than mean summer air temperatures (A.F. Lotter, unpublished data). Thus, if the same relationship existed during the Lateglacial this would imply Younger Dryas July air temperatures around 10$11^{\circ} \mathrm{C}$ at Gerzensee. In the northern Swiss Alps, the decrease in present-day July air temperatures with altitude is estimated as being $0.6^{\circ} \mathrm{C}$ per $100 \mathrm{~m}$ (Livingstone et al., 1999). Assuming comparable lapse rates for the Lateglacial period, the chironomidinferred temperatures at Hinterburgsee corrected to an altitude of $600 \mathrm{~m}$ a.s.l. would therefore be $c .16^{\circ} \mathrm{C}$, or $5-6^{\circ} \mathrm{C}$ warmer than those inferred for Gerzensee. However, the Lateglacial samples in the Hinterburgsee chironomid record are strongly affected by analogue problems, by a comparatively high proportion of rare taxa and by a 'poor fit' to temperature. Furthermore, the inferred temperatures may already be influenced by the edge effects of the chironomid-temperaturecalibration model. Nevertheless, the large discrepancy between the reconstructions raises the question whether the Younger Dryas summer temperature estimates of Lotter et al. (2000) may be too low. Further Lateglacial temperature reconstructions based on models less affected by edge effects and analogue problems are necessary to resolve this issue.

With the exception of two distinct short-term cool periods, the smoothed Holocene temperature reconstruction of Hinterburgsee can be split into three parts (Figure 5, b and c): (1) the early to mid-Holocene (11500-4000 cal. BP) with temperatures between 11.9 and $12.8^{\circ} \mathrm{C}, c .0 .6-1.6^{\circ} \mathrm{C}$ warmer than today; (2) the late Holocene (3500-1000 cal. BP) with temperatures between 11.5 and $12^{\circ} \mathrm{C}$, only 0.2 to $0.7^{\circ} \mathrm{C}$ warmer than today; and (3) the last millennium BP, again with higher temperatures reaching 12.4 to $12.8^{\circ} \mathrm{C}$.

Due to changes in the Earth-Sun geometry, the maximum Holocene summer insolation at northern latitudes was reached at c. 9000 cal. BP (Kutzbach and Webb, 1993). Congruously, Holocene climate reconstructions in Europe generally infer high summer temperatures in the early and mid-Holocene and lower temperatures in the past few millennia. In western Scandinavia, the highest Holocene temperatures based on palaeobotanical and glacier equilibrium-line reconstructions are generally inferred for the period between c. 9500 and 5000-6000 cal. BP, with a decreasing trend during the rest of the Holocene (e.g., Dahl and Nesje, 1996; Matthews et al., 2000). The maximum treeline elevation in the Swiss Alps has been inferred from c. 9000-8000 cal. BP to 5400-5000 cal. BP (Lang, 1993; Wick, 1994; Tinner et al., 1996). However, the first human induced lowering of treeline may have taken place as early as $c .5500 \mathrm{cal}$. BP (Lang, 1993; Tinner et al., 1996) and, therefore, climatological interpretations of the treeline depressions since the mid-Holocene may be biased by local human activity. At Hinterburgsee, a decrease in the smoothed temperature reconstructions from high values in the early and mid-Holocene to lower values in the late Holocene takes place fairly abruptly between c. 4000 and 3700 cal. BP (note, however, that this trend is strongly influenced by a single sample; Figure 5). This is about 1000-1500 years later than might be inferred from treeline depressions. Nevertheless, a major change in Holocene climate between $c .4000$ and 3500 cal. BP is supported by other European summer air temperature reconstructions: After 6000 years of virtually having been absent, glaciers in the eastern Swiss Alps formed again between c. 4000 and $3500 \mathrm{cal}$. $\mathrm{BP}$ and have persisted during the rest of the Holocene (Leemann and Niessen, 1994). According to Leemann and Niessen (1994), this is most likely a consequence of lower summer temperatures. Similarly, Nesje et al. (2001) present results indicating glacier advances in western Norway after $4000 \mathrm{cal}$. BP. Furthermore, Anderson et al. (1998) describe an abrupt shift to wetter and possibly cooler conditions in northern Scotland between 3900 and $3500 \mathrm{cal}$. BP. At Hinterburgsee, inferred temperatures remain below $12^{\circ} \mathrm{C}$ between 3500 and $1000 \mathrm{cal}$. BP, only to rise again during the last millennium BP. Such a strong increase in summer temperatures is not evident in other temperature reconstructions. On the contrary, the past few hundred years before the twentieth century are considered to be among the coolest experienced during the Holocene (Bradley, 2000). Obviously, the Hinterburgsee chironomid-temperature reconstruction fails to track this cooler climate. Palaeobotanical evidence indicates strongly increased human activity near Hinterburgsee (opening of the catchment vegetation and pasturing) starting from $c .1000 \mathrm{cal}$. BP (Heiri et al., 2003). The presence of humans and livestock in a lake's catchment can increase the nutrient loading of the lake, thereby changing the trophic conditions to be more typical of sites of lower elevation. The temporal agreement between the increasing human activity near Hinterburgsee and the rise in chironomid-inferred temperatures therefore suggests that this recent trend is a bias due to anthropogenic impact on the lake ecosystem.

\section{Climate reversals}

The two strongest Holocene climatic fluctuations in the chironomid reconstruction are the decrease of inferred July air temperatures at $c .10700-10500$ and at $c .8200-7700 \mathrm{cal}$. BP (henceforth referred to as events $\mathrm{A}$ and $\mathrm{B}$ ). In consideration of the uncertainty in our age-depth model, cold periods with a similar age as event A have been inferred from the Swiss and Austrian Alps (e.g., Patzelt, 1977; Wick and Tinner, 1997; Haas et al., 1998) and from Western Scandinavia (e.g. Dahl and Nesje, 1994; Matthews et al., 2000). In central Europe, the timing of a major early-Holocene cold event has been reported as 10750-10200 cal. BP (Haas et al., 1998) and in southern Norway and the North Atlantic region as 10300 cal. BP (Matthews et al., 2000; Björck et al., 2001). The decrease in summer air temperature has been estimated to $0.8^{\circ} \mathrm{C}$ (Haas et al., 1998) for the Swiss Alps, which agrees well with both of our smoothed temperature reconstructions, suggesting a decline in July air temperature of $0.6-0.8^{\circ} \mathrm{C}$ (note, however, that in the unsmoothed temperatures the decrease is $\left.1.7^{\circ} \mathrm{C} !\right)$. The beginning of event $\mathrm{B}$ coincides with a widely reported temperature decline around the North Atlantic. Oxygen isotopes measured in the Greenland ice cores and in lake marls in the Alpine foreland of southern Germany indicate a significant annual temperature decrease at $8200 \mathrm{cal}$. BP, lasting about 100 to 200 years (Alley et al., 1997; von Grafenstein et al., 1998) and estimated to be of a decline of $1.7^{\circ} \mathrm{C}$ in mean annual temperature in southern Germany (von Grafenstein et al., 1998). A cold event of a similar age is well represented in many northern and central European reconstructions of Holocene summer air temperature (e.g., Dahl and Nesje, 1996; Wick and Tinner, 1997; Haas et al., 1998; Matthews et al., 2000; Nesje and Dahl, 2001) and estimated to be of a summer temperature decrease of between $0.8^{\circ} \mathrm{C}$ in the Alps (Haas et al., 1998) and $1.2^{\circ} \mathrm{C}$ in Norway (Dahl and Nesje, 1996). At Hinterburgsee this cooling episode (event B) starts at c. 8200 
cal. BP and, depending on the smoothing of the reconstruction, lasts a minimum of 300-400 years. Smoothed chironomid inferred temperatures indicate a decrease of July air temperatures of about $1{ }^{\circ} \mathrm{C}$, but again the decrease in unsmoothed temperatures is stronger and amounts to $c .2^{\circ} \mathrm{C}$ (Figure 5). It is intriguing that the duration of event $\mathrm{B}$ at Hinterburgsee is significantly longer than the cold event registered in oxygen-isotope measurements in Greenland and in southern Germany (Alley et al., 1997; von Grafenstein et al., 1998) and this raises the question if there existed a longer period of cooler summer temperatures around $8000 \mathrm{cal}$. BP in Europe than has previously been assumed based on isotope measurements. However, three of the radiocarbon samples in our age-depth model have an age close to $8200 \mathrm{cal}$. BP (Figure 2) and an alternative explanation may be that our model underestimates the sedimentation rate during this part of the core and therefore overestimates the duration of this cold event.

\section{Summary and conclusions}

(1) On the basis of a chironomid-air temperature calibration model, low July air temperatures of $10.4-10.9^{\circ} \mathrm{C}$ were reconstructed at Hinterburgsee for the end of the Younger Dryas, high temperatures of $11.9-12.8^{\circ} \mathrm{C}$ during the early and mid-Holocene (11500-4000 cal. BP) and again lower temperatures of 11.5$12.0^{\circ} \mathrm{C}$ during the late Holocene (3500-1000 cal. BP). Higher temperatures are again inferred from the youngest samples (after $1000 \mathrm{cal}$. BP). Since there is evidence of strong regional human impact near Hinterburgsee during this period, and since this warming trend runs contrary to other summer-temperature reconstructions, we consider it to be an artefact of local human activity.

(2) According to the smoothed temperature reconstructions the most significant climatological events at Hinterburgsee were two periods of lower July air temperatures of $11.1-11.4^{\circ} \mathrm{C}$ during the early and mid-Holocene (c. 10700-10500 and 8200-7700 cal. $\mathrm{BP}$ ) and the abrupt shift to cooler July air temperatures at $c$. 40003700 cal. BP.

(3) The reconstructed Holocene temperature changes are within the prediction error of the chironomid-July air temperature inference model. Furthermore, the amplitudes of the fluctuations are certainly influenced by the smoothing of the inferred temperature values (for reconstruction 1 ) or of the raw chironomid percentage data (for reconstruction 2). Nevertheless, the improved evaluation statistics of reconstruction 2 indicate that due to a high variability in the Hinterburgsee subfossil chironomid record the smoothed temperatures provide a more reliable temperature estimate than the unsmoothed inferences.

(4) Clearly a higher temporal resolution is needed to reduce the bias of smoothing on our temperature inferences and to fully quantify the extent and duration of major Holocene summertemperature fluctuations in the Swiss Alps. Nonetheless, our results underline the potential of chironomid-based temperature inference models to track not only the high amplitude climatic reversals of the Lateglacial, but also the weaker climate events in the Holocene.

\section{Acknowledgements}

Additional lake-surface sediments for the expansion of the chironomid-temperature inference model have kindly been made available by J. Guthruf, M. Zeh, W. Tinner and S. Dimitriadis. We thank W. Hofmann for making the original sample protocols and chironomid slides of the first Swiss surface-sediment transect available for this study, and H.J.B. Birks and E. Heegard for providing the age-depth model for Hinterburgsee. E. Sayer helped improve the language in this manuscript. Funding was provided by the Swiss Federal Office of Education and Science (Grant No. 97.0117) within the framework of the European Union Environment and Climate project CHILL-10,000 ('Climate history as recorded by ecologically sensitive arctic and alpine lakes during the last 10,000 years: a multi-proxy approach'; Contract No. ENV4-CT97-0642) and by the Swiss National Science Foundation within the framework of Priority Programme Environment (project 5001-044600).

\section{References}

Alley, R.B., Mayewski, P.A., Sowers, T., Stuiver, M., Taylor, K.C. and Clark, P.U. 1997: Holocene climatic instability: a prominent, widespread event 8200 yr ago. Geology 25, 483-86.

Ammann, B. and Wick, L. 1993: Analysis of fossil stomata of conifers as indicators of the alpine tree line fluctuations during the Holocene. In Frenzel, B., Eronen, M., Vorren, K.-D. and Gläser, B., editors, Oscillations of the alpine and polar tree limits in the Holocene, Stuttgart: Gustav Fischer Verlag, 177-85.

Anderson, D.E., Binney, H.A. and Smith, M.A. 1998: Evidence for abrupt climatic change in northern Scotland between 3900 and 3500 calendar years BP. The Holocene 8, 97-103.

Battarbee, R.W. 2000: Palaeolimnological approaches to climate change, with special regard to the biological record. Quaternary Science Reviews 19, 107-24.

Bircher, W. 1986: Dendrochronology applied in mountain regions. In Berglund, B.E., editor, Handbook of Holocene palaeoecology and palaeohydrology, Chichester: Wiley, 387-403.

Birks, H.J.B. 1995: Quantitative palaeoenvironmental reconstructions. In Maddy, D. and Brew, J.J., editors, Statistical modelling of Quaternary science data, Cambridge: Quaternary Research Association, 161-254.

— 1998: Numerical tools in palaeolimnology - progress, potentialities, and problems. Journal of Paleolimnology 20, 307-32.

Birks, H.J.B., Line, J.M., Juggins, S., Steveson, A.C. and ter Braak, C.J.F. 1990: Diatoms and $\mathrm{pH}$ reconstruction. Philosophical Transactions of the Royal Society of London B 327, 263-78.

Björck, S., Muscheler, R., Kromer, B., Andresen, C.S., Heinemeier, J., Johnsen, S., Conley, D., Koç, N., Spurk, M. and Veski, S. 2001: High resolution analyses of an early Holocene climate event may imply decreased solar forcing as an important climate trigger. Geology 29, 1107-10.

Bradley, R.S. 2000: Past global changes and their significance for the future. Quaternary Science Reviews 19, 391-402.

Brooks, S.J. and Birks, H.J.B. 2000a: Chironomid-inferred Late-glacial air temperatures at Whitrig Bog, southeast Scotland. Journal of Quaternary Science 15, 759-64.

2000b: Chironomid-inferred late-glacial and early-Holocene mean July air temperatures for Kråkenes Lake, western Norway. Journal of Paleolimnology 23, 77-89.

Burga, C.A. and Perret, R. 1998: Vegetation und Klima der Schweiz seit dem jüngeren Eiszeitalter. Thun: Ott Verlag and Druck AG, 805 pp.

Cleveland, W.S. and Devlin, S.J. 1988: Locally-weighted regression: an approach to regression analysis by local fitting. Journal of the American Statistical Association 83, 596-610.

COHMAP Members 1988: Climatic changes of the last 18,000 years: observations and model simulations. Science 241, 1043-52.

Dahl, E. 1986: Zonation in arctic and alpine tundra and fell field ecotones. In Pollunin, N., editor, Ecosystem theory and application, Chichester: Wiley, 33-62.

Dahl, S.O. and Nesje, A. 1994: Holocene glacier fluctuations at Hardangerjokulen, central southern Norway. The Holocene 4, 269-77.

1996: A new approach to calculating Holocene winter precipitation by combining glacier equilibrium-line altitudes and pine-tree limits: a case study from Hardangerjokulen, central southern Norway. The Holocene 6, 381-98.

Francis, D.R. 2001: A record of hypolimnetic oxygen conditions in a temperate multi-depression lake from chemical evidence and chironomid remains. Journal of Paleolimnology 25, 351-65.

GRIP Members 1993: Climate instability during the last interglacial period recorded in the GRIP ice core. Nature 364, 203-207. 
Haas, J.N., Richoz, I., Tinner, W. and Wick, L. 1998: Synchronous Holocene climate oscillations recorded on the Swiss Plateau and at timberline in the Alps. The Holocene 8, 301-309.

Hastie, T. and Tibshirani, R. 1990. Generalized additive models. London: Chapman and Hall, 335 pp.

Heiri, O. 2001: Holocene palaeolimnology of Swiss mountain lakes reconstructed using subfossil chironomid remains: past climate and prehistoric human impact on lake ecosystems. PhD thesis, University of Bern, $113 \mathrm{pp}$ Heiri, O. and Lotter, A.F. 2001: Effect of low count sums on quantitative environmental reconstructions: an example using subfossil chironomids. Journal of Paleolimnology 26, 343-50.

Heiri, O., Wick, L., van Leeuwen, J.F.N., van der Knaap, W.O. and Lotter, A.F. 2003: Holocene tree immigration and the chironomid fauna of a small Swiss subalpine lake (Hinterburgsee, $1515 \mathrm{~m}$ asl). Palaeogeography, Palaeoclimatology, Palaeoecology 189, 35-53.

Hill, M.O. 1973: Diversity and evenness: a unifying notation and its consequences. Ecology 54, 427-32.

Jones, V.J. and Juggins, S. 1995: The construction of a diatom-based chlorophyll a transfer function and its application at three lakes on Signy Island (maritime Antarctic) subject to differing degrees of nutrient enrichment. Freshwater Biology 34, 433-45.

Korsman, T., Renberg, I. and Anderson, N.J. 1994: A palaeolimnological test of the influence of Norway spruce (Picea abies) immigration on lake water acidity. The Holocene 4, 132-40.

Kutzbach, J.E. and Webb, T. III 1993: Conceptual basis for understanding Late-Quaternary climates. In Wright, H.E. Jr., editor, Global climates since the last glacial maximum, Minneapolis: University of Minnesota Press, 5-11.

Lang, G. 1993: Holozäne Veränderungen der Waldgrenze in den Schweizer Alpen - Methodische Ansätze und gegenwärtiger Kenntnisstand. Dissertationes Botanicae 196, 317-27.

Leemann, A. and Niessen, F. 1994: Holocene glacial activity and climatic variations in the Swiss Alps: reconstructing a continuous record from pro-glacial lake sediments. The Holocene 4, 259-68.

Levesque, A.J., Mayle, F.E., Walker, I.R. and Cwynar, L.C. 1993: A previously unrecognized late-glacial cold event in eastern North America. Nature 361, 623-26.

Livingstone, D.M., Lotter, A.F. and Walker, I.R. 1999: The decrease in summer water temperature with altitude in Swiss alpine lakes: a comparison with air lapse rates. Arctic, Antarctic and Alpine Research 31, 341-52.

Lotter, A.F., Birks, H.J.B., Eicher, U., Hofmann, W., Schwander, J. and Wick, L. 2000: Younger Dryas and Allerød summer temperatures at Gerzensee (Switzerland) inferred from fossil pollen and cladoceran assemblages. Palaeogeography, Palaeoclimatology, Palaeoecology 159, 349-61.

Lotter, A.F., Birks, H.J.B., Hofmann, W. and Marchetto, A. 1997: Modern diatom, cladocera, chironomid, and chrysophyte cyst assemblages as quantitative indicators for the reconstruction of past environmental conditions in the Alps. I. Climate. Journal of Paleolimnology 18, 395-420. _ 1998: Modern diatom, cladocera, chironomid, and chrysophyte cyst assemblages as quantitative indicators for the reconstruction of past environmental conditions in the Alps. II. Nutrients. Journal of Paleolimnology 19, 443-63.

Matthews, J.A., Dahl, S.O., Nesje, A., Berrisford, M.S. and Andersson, C. 2000: Holocene glacier variations in central Jotunheimen, southern Norway, based on distal glaciolacustrine sediment cores. Quaternary Science Reviews 19, 1625-47.

Müller, B., Lotter, A.F., Sturm, M. and Ammann, A. 1998: Influence of catchment quality and altitude on the water and sediment composition of 68 small lakes in Central Europe. Aquatic Sciences 60, 316-37.

Nesje, A. and Dahl, S.O. 2001: The Greenland 8200 cal. yr BP event detected in loss-on-ignition profiles in Norwegian lacustrine sediment sequences. Journal of Quaternary Science 16, 155-66.

Nesje, A., Matthews, J.A., Dahl, S.O., Berrisford, M.S. and Andersson, C. 2001: Holocene glacier fluctuations of Flatebreen and winter-precipitation changes in the Jostedalsbreen region, western Norway, based on glaciolacustrine sediment records. The Holocene 11, 267-80.

Patzelt, G. 1977: Der zeitliche Ablauf und das Ausmass postglazialer
Klimaschwankungen in den Alpen. In Frenzel, B., editor, Dendrochronologie und postglaziale Klimaschwankungen in Europa, Wiesbaden: F. Steiner Verlag, 248-59.

Pellatt, M.G., Smith, M.J., Mathewes, R.W., Walker, I.R. and Palmer, S.L. 2000: Holocene treeline and climate change in the subalpine zone near Stoyoma Mountain, Cascade Mountains, Southwestern British Columbia, Canada. Arctic, Antarctic, and Alpine Research 32, 73-83.

Renberg, I., Korsman, T. and Birks, H.J.B. 1993: Prehistoric increase in the $\mathrm{pH}$ of acid-sensitive Swedish lakes caused by land-use changes. Nature 362, 824-27.

Renssen, H. and Isarin, R.F.B. 1998: Surface temperature in NW Europe during the Younger Dryas: AGCM simulation compared with temperature reconstructions. Climate Dynamics 14, 33-44.

Rosén, P., Segerström, U., Eriksson, L., Renberg, I. and Birks, H.J.B. 2001: Holocene climatic change reconstructed from diatoms, chironomids, pollen and near-infrared spectroscopy at an alpine lake (Sjuodjijaure) in northern Sweden. The Holocene 11, 551-62.

Schweingruber, F.H., Briffa, K.R. and Jones, P.D. 1991: Yearly maps of summer temperatures in western Europe from AD 1750 to 1975 and western North America from 1600 to 1982: results of a radiodensitometrical study on tree rings. Vegetatio 92, 5-71.

Smith, M.J., Pellat, M.G., Walker, I.R. and Mathewes, R.W. 1998: Postglacial changes in chironomid communities and inferred climate near treeline at Mount Stoyoma, Cascade mountains, southwestern British Columbia, Canada. Journal of Paleolimnology 20, 277-93.

Spengler, D. 1973: Limnologische, hydrologische und morphologische Untersuchungen im Faulhorngebiet (Berner Oberland). $\mathrm{PhD}$ thesis, University of Bern, 155 pp.

Stuiver, M. and Reimer, P.J. 1993: Extended ${ }^{14} \mathrm{C}$ data base and revised CALIB radiocarbon calibration program. Radiocarbon 35, 215-30.

ter Braak, C.J.F. 1990: Update notes: CANOCO version 3.10. Wageningen: Agricultural Mathematics Group, $35 \mathrm{pp}$

— 1992: Permutation versus bootstrap significance tests in multiple regression and ANOVA. In Jöckel, K.-H., Rothe, G. and Sendler, W., editors, Bootstrapping and related techniques, Berlin: Springer-Verlag, 79-86.

ter Braak, C.J.F. and Juggins, S. 1993: Weighted averaging partial least squares regression (WA-PLS): an improved method for reconstructing environmental variables from species assemblages. Hydrobiologia 269/270, 485-502.

ter Braak, C.J.F. and Smilauer, P. 1998: CANOCO reference manual and user's guide to Canoco for windows. Wageningen: Centre for Biometry Wageningen, $352 \mathrm{pp}$.

ter Braak, C.J.F., Juggins, S., Birks, H.J.B. and van der Voet, H. 1993: Weighted averaging partial least squares regression (WA-PLS): definition and comparison with other methods for species-environmental calibration. In Patil, G.P. and Rao, C.R., editors, Multivariate environmental statistics, Amsterdam: Elsevier Science Publishers, 525-60.

Tinner, W., Ammann, B. and Germann, P. 1996: Treeline fluctuations recorded for 12,500 years by soil profiles, pollen, and plant macrofossils in the Central Swiss Alps. Arctic and Alpine Research 28, 131-47.

Tranquillini, W. 1979. Physiological ecology of the alpine timberline: tree existence at high altitudes with special reference to the European Alps. Berlin: Springer, 137 pp.

von Grafenstein, U., Erlenkeuser, H., Müller, J., Jouzel, J. and Johnsen, S. 1998: The cold event 8200 years ago documented in oxygen isotope records of precipitation in Europe and Greenland. Climate Dynamics 14, 73-81.

Walker, I.R., Mott, R.J. and Smol, J.P. 1991a: Allerød-Younger Dryas lake temperatures from midge fossils in Atlantic Canada. Science 253, 1010-12.

Walker, I.R., Smol, J.P., Engstrom, D.R. and Birks, H.J.B. 1991b: An assessment of Chironomidae as quantitative indicators of past climatic change. Canadian Journal of Fisheries and Aquatic Sciences 48, 975-87. Wick, L. 1994: Early-Holocene reforestation and vegetation change at a lake near the alpine forest limit: Lago Basso (2250 m asl), Northern Italy. Dissertationes Botanicae 234, 555-63.

Wick, L. and Tinner, W. 1997: Vegetation changes and timberline fluctuations in the Central Alps as indicators of Holocene climate fluctuations. Arctic and Alpine Research 29, 445-58. 